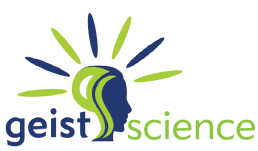

\title{
Journal of Management Sciences
}

\section{Protean Career Orientation and Subjective} Career Success: A Cross-Cultural Perspective

\section{Affiliation:}

Junaid Zafar

Assistant Professor, Department of Commerce, Bahauddin Zakariya

University, Multan. Email: junaidzafar@bzu.edu.pk

Muhammad Umer Quddoos

Assistant Professor, Department of Commerce, Bahauddin Zakariya

University, Multan. Email: umerattari@bzu.edu.pk

Muhammad Munir Ahmad

Lecturer, Department of Commerce, Allama Iqbal Open University, Islamabad.

\section{Manuscript Information}

Submission Date: February 28, 2021

Reviews Completed: May 11, 2021

Acceptance Date: June 18, 2021

Publication Date: June 30, 2021

\section{Citation in APA Style:}

Zafar, J., Quddoos, M. U., \& Ahmad, M. M. (2021). Protean Career Orientation and Subjective Career Success: A Cross-Cultural Perspective, Journal of Management Sciences, 8(2), 1-10.

DOI: https://doi.org/10.20547/jms.2014.2108201 


\title{
Protean Career Orientation and Subjective Career Success: A Cross-Cultural Perspective
}

\author{
Junaid Zafar* $\quad$ Muhammad Umer Quddoos ${ }^{\dagger} \quad$ Muhammad Munir Ahmad $\ddagger$
}

\begin{abstract}
The study is cross-cultural and finds out the career concepts such as protean career and career success as practiced in the developed economies. A protean career mindset calls for professionals in the advanced economies looking to switch tasks, departments, and acquire new skills, so as to remain employable. Furthermore, the traditional paternalistic model of career movement by working for one employer during a lifetime is gradually losing its form. However, more developing counties need to be studied so as to figure out the protean career orientation as leading to their career success. The research was conducted with academics working in Pakistan's private sector universities. The private sector is commercialized and innovative, and thus fits well with the career concepts discussed in the study. The sample was chosen out of a total population of 4,994 academics present within the 35 private sector universities located across the country. Hypothesis was measured and has not been supported in the research finding, as there is a statistically insignificant relationship between the variables with $\beta=.131, z$-value $=1.153$ and $p>.05$. The statistically insignificant relationship shows that the career concepts such as protean career orientation and subjective career success are more akin to "individualistic" styles of management, and less prevalent in "collectivistic" Pakistani culture.
\end{abstract}

Keywords: Subjective career success, protean career orientation, private education sector, protean career theory

\section{Introduction}

Baruch and Hall (2004) argued that academic careers are unique. According to these researchers, an academic at a university is independent to self manage his career and takes charge of his self-development. Academic careers are thus a role model for the "new careers" such as the protean career.

Another important concept discussed extensively in the modern economy is subjective career success. It has been defined by Seibert, Crant, and Kraimer (1999) as the evaluation of accomplishments, career progress, and anticipated outcomes relative to the goals and aspirations set by career enthusiasts. However, the concept of protean career is seldom present in Pakistani literature, especially with regard to the subjective career success of

\footnotetext{
*Assistant Professor, Department of Commerce, Bahauddin Zakariya University, Multan. Email: junaidzafar@bzu.edu.pk

${ }^{\dagger}$ Assistant Professor, Department of Commerce, Bahauddin Zakariya University, Multan. Email: umerattari@bzu.edu.pk

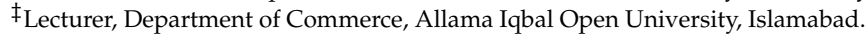

Received February 28, 2021; Received in revised form May 11, 2021; Accepted June 18, 2021; Available online June 30, 2021 
private sector academics. Furthermore, there remain loopholes in the private HEI's of Pakistan that need attention and action. The private sector academics in Pakistan are faced with living standards that are not at par with those in the more technologically and economically advanced part of the world.

\section{Literature Review}

From the definition of subjective career success, it seems clear that career is a process or pattern of events unfolding in the life of an individual. So career can be taken to be both descriptive and evaluative (Arthur, Khapova, \& Wilderom, 2005; Briscoe \& Hall, 2006; De Vos \& Soens, 2008). Career is descriptive for an individual, as it includes the life events unfolding such as job switches, transitions, joblessness, migrations and education. And career is also evaluative, meaning an increase in one's status, pay and rank. In some literature on career studies, subjective career success is operationalized as career satisfaction or job satisfaction. Job satisfaction is the feeling one has after an evaluation of his or her job situation (Yousaf \& Sanders, 2012). In a meta-analysis by Ng, Eby, Sorensen, and Feldman (2005), subjective career success was operationalized only as career satisfaction. Researchers have thus tried to capture success in the form of career satisfaction or job satisfaction.

Protean Career Orientation has been defined by Direnzo and Greenhaus (2011) as an individual managing his or her career in a proactive, self-directed way driven by personal values and subjective success criteria. A protean career is marked by varied experiences that a person holds during his or her lifetime, especially in formal education, training and development, organizational changes, job changes and market upheavals. It is only through this life-long continuous learning that employees with a protean career adjust to newer skills, abilities and opportunities, and increase their chances of employability within the labor market (Briscoe, Hall, \& DeMuth, 2006). With the emergence of more dynamic economic conditions marked by recessions, downsizing, mergers, acquisitions, and newer career structures, the various career attitudes and behaviors have changed. The dynamic market conditions have resulted in the "protean career model", which is more of an "adult-adult relationship", where the individual takes charge of his or her own destiny (Cao, Hirschi, \& Deller, 2013; Grimland, Vigoda-Gadot, \& Baruch, 2012). Owing to this self-directed nature of the protean career architect, protean career is described as one that is under the control of the employee rather than the employer. So the protean careerist owing to his self-directed nature tends to change shapes to suit his or her own personal ambitions, and career goals.

The Pakistani researchers have discussed various factors like location, class size, experience, gender, age, education, pay, promotional prospects, recognition of achievement, administrative support, interpersonal relations, nature of work, autonomy, decision making ability, and fringe benefits to effect the job success. But, there is no mention of protean career orientation in relation to subjective career success of academics. There is a study by A. Chaudhry (2013) on the foreign multinationals operating in Pakistan with respect to the "new career" concepts like protean career attitude but it is a qualitative study and not 
focused on the higher education sector. It is, therefore, important to study the relationship between protean career orientation and subjective career success.

\section{Protean Career Theory}

To give support to the conceptual framework, the researcher has taken the protean career theory as the underpinning theory. Protean career theory has an emphasis on dispositions, and attitudes leading to subjective career success (Briscoe \& Hall, 2006). The theory suggests that having a protean career is tied with strong internal, psychological motivations. Also knowledge, skills and attitudes (KSA's) are needed for employability in the labor market. A career marked by protean attitude has an extreme form of boundarylessness and career subjectivity (Baruch \& Hall, 2004). Professionals pursuing a protean career try to maintain a psychological contract with themselves rather than with an organization. Such types take charge of their career development and try to shape themselves in accordance with the career desires and the changing market.

Therefore, a person pursing a protean career emphasizes a meaningful career path expressed by human potential (Hall, 2004). They have a sense of purpose and try to intermix the career with the self. The protean career is an extension of self-expression or a vehicle for growth, and helps in achieving personally meaningful goals

\section{Hypothesis Development}

With the emergence of linear career and transactional psychological contracts, company loyalty has been tarnished where career aspirants have become more self-driven rather than being reliant on the organization for their subjective career success (Sullivan \& Baruch, 2009). A process of negotiation takes place between the career aspirants and the organizations. Professionals thus expect little or no job security, frequent career movements, and lower career satisfaction due to their strained ties within the unpredictable labor environment. This has resulted in the appearance of more dynamic career paths, such as protean and boundaryless careers where, professionals have taken the lead in managing their careers (Baruch \& Hall, 2004; Sullivan \& Baruch, 2009).

Furthermore, it must be stated that subjective career success is how one feels about her or her career, and is a reaction to the experiences unfolding in one's career. These experiences have thus emerged with the evolution of protean career orientations. Hall (2004) describes protean career orientation as the "career learning cycle" in which the person with a protean career mindset tries to achieve psychological success. Therefore, it is hypothesized that:

\section{H1: There is a relationship between PCO and SCS}

Ho: There is no significant relationship between PCO and SCS 
Figure 1

Theoretical Model of the study

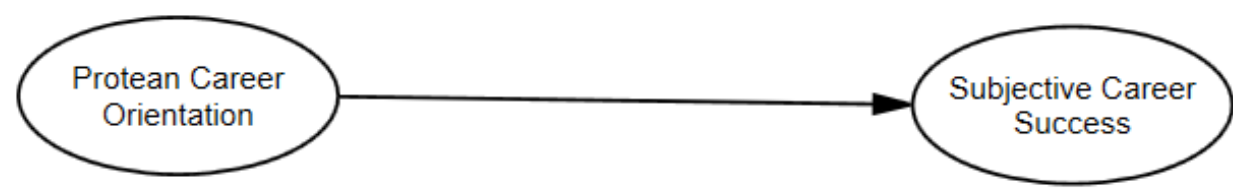

\section{Methodology}

The study was conducted by taking into account a total of 194 academics from various private sector universities located in the country. Before, an explanation of sampling technique is given, the researcher would like to clarify that the private sector universities were recognized by the Higher Education Commission of the country. The HEC is the de facto body responsible for setting standards within the country and maintaining a strategic liaison with other universities outside the country. The commission divides the private sector higher education institutes into two categories i.e. those having a " $W$ " rank and those having "non- $W$ " rank. The "non- $W$ " are short of certain quality requirements and cannot hold MS/PhD classes at their campus; while, the "W" category universities can have MS/ PhD classes and subsequent supervision. The " $\mathrm{W}$ " rank is further divided into W1, W2, W3 and W4 with lowest to the highest.

The sampling technique used by the researcher is proportionate stratified sampling. This technique enables the researchers to minimize the bias and have all individuals within the sample have equal chance of representation. There are four strata included in the present study i.e. professor, associate professor, assistant professor and lecturer. This process of stratification has also been used by S. Chaudhry (2013) in their studies.

\section{Measure of Subjective Career Success}

The dependent variable for the present study is subjective career success. It has five items and has an excellent internal reliability of $\alpha=.88$. The instrument was originally used by Greenhaus, Parasuraman, and Wormley (1990) and is known as the "Career Satisfaction Questionnaire".

\section{Measure of Protean Career Orientation}

The independent variable for the present study is protean career orientation. It has six items with a superb internal reliability $(\alpha=.85)$. The instrument was developed by Bridgstock (2007)and is known as the "protean career orientation scale" (PCOS). 


\section{Data Analysis}

The data analysis for the present study was done by Statistical Package for the Social Sciences (SPSS) and Analysis of Moment Structures (AMOS). The SPSS was used for finding out the missing data, non-respondent bias, outliers and normality. Meanwhile, the conducting confirmatory factor analysis and testing for the hypotheses was done by AMOS.

\section{Results}

The structural model given below in figure shows the hypothesized model and the relationships among the different latent constructs (Hair, Black, Babin, Anderson, \& Tatham, 2006). It must be kept in mind that the structural model (SM) is only had after the constructs have been defined, the measurement model developed and the validity of the model been sorted out. The structural model thus only shows the hypothetical model and the relationships among the various constructs.

The value in the model as proposed by Garver and Mentzer (1999) is given in the Table below:

\begin{tabular}{lcc}
$\begin{array}{l}\text { Table } \mathbf{1} \\
\text { Model Fit }\end{array}$ & \multicolumn{2}{l}{} \\
\hline Index & Ideal Fit & Observed Fit \\
\hline Non-normed fit index (NNFI) or Tucker Lewis Index (TLI) & $>.90$ & 0.89 \\
Root Mean Square Approximation of Error (RMSEA) & $<.08$ & 0.86 \\
Comparative Fit Index (CFI) & $>.90$ & 0.92 \\
$X^{2}$ / D.F. ratio & Equal to or Less than 3 & 2.30 \\
Goodness-of-fit Index (GFI) & $>.90$ & 0.91 \\
Adjusted Goodness-of-fit Index (AGFI) & $>.80$ & 0.86 \\
\hline
\end{tabular}

The direct effects are shown by the structural model. The results of the direct relationship are shown below:

Table 2

Directs Effect

\begin{tabular}{|c|c|c|c|c|c|}
\hline & Est. & S.E. & C.R. & $\mathbf{P}$ & Status \\
\hline $\mathrm{SCS} \leftarrow \mathrm{PCO}$ & 0.13 & 0.11 & 1.15 & 0.25 & Not Sig \\
\hline
\end{tabular}

The positive and statistically significant relationship between protean career orientation and subjective career success has not been observed from the direct effects as given in the Table above. The relationship between the two variables has thus been found to be statistically insignificant as $\beta=.131, \mathrm{z}$-value $=1.15$ and $\mathrm{p}>.05$. Therefore, the hypothesis is rejected. 


\section{Discussion}

The hypothesis has not been supported in the research finding, as there is a statistically insignificant relationship between the two variables with $\beta=.131$, $\mathrm{z}$-value $=1.153$ and $\mathrm{p}>$.05.

Some of the reasons for this insignificant relationship is the fact that the "new career" concepts such as protean career are more akin to "individualistic" styles of management, and less prevalent in "collectivistic" Pakistani culture. According to Ohbuchi, Fukushima, and Tedeschi (1999), individualistic counties like the US tend to have preference for individualized goals, whereas collectivistic societies like Pakistan tend to look towards the needs of the entire group. The Pakistani business environment is not as dynamic as the industrialized economies marked by downsizing, mergers, acquisitions, and more flexible career structures. The very concept of "downsizing" is a Western term, whereby (Hirsch, 1988) discussed job mobility to be the overriding variable especially in hard time like takeovers and downsizing. During the Global Economic Recession of 2007-2012, subjective career success was seen in light of protean career especially in Anglo-American literature. The dynamic market conditions in the industrialized nations have thus resulted in the "protean career model", which is more of an "adult-adult relationship", where the individual takes charge of his destiny, and ensures career satisfaction.

Furthermore, the insignificant relationship between protean career orientation (PCO) and subjective career success (SCS) in the present study is not in congruence with the findings of Volmer and Spurk (2011) or those of De Vos and Soens (2008) who found individuals with protean career orientation having higher levels of career satisfaction. The findings are also not supporting (Hall, 2004) who described protean career orientation as the "career learning cycle". It is these continuous learning experiences that result in psychological success of professionals. The implication being carried forward from the present study is that the academics are not setting challenging goals, and putting in one's best efforts resulting in the satisfaction of academics in their career.

The present study also does not support the view given by Briscoe and Finkelstein (2009) who describe protean career actors as not particularly attracted to career development opportunities provided by the employing organization, and aim for alternative career development initiatives with external employers and organizations. The statistically insignificant relationship of protean career orientation with subjective career success thus depicts the fact that the academics are not yet fully ready for external career opportunities leading to psychological success. Academics are in a weak position to expect career management from the employer given the highly competitive labor market where positions are insecure and easily replaced. Academics are thus not encouraged to manage their own careers given the lack of external opportunity. Another implication of this finding is that the academics thus lack an internal guide which is crucial in making career related decisions that are the foundations for career satisfaction.

The findings of the present study are also not representative of the study conducted by Gasteiger (2007) who found a positive relationship between protean career orientation and subjective career success. Gasteiger's (2007) study was conducted among German executives and professionals who are value-driven and self-directed, and thus represen- 
tative of a protean career orientation. However, academics in Pakistan due to limited job market are not as self-driven as professionals in the more industrialized nations. The statistically insignificant relationship is, however, in congruence with the findings of Sullivan and Arthur (2006) who point towards protean career orientation being more of a "Western" concept found in individualistic societies; countries where the labor force is more mobile, and are focused on material rewards, and promotional gains. The "new career" concept of protean career is not noticeable among the academics in the present study where, protean career orientation has a significant relationship with subjective career success. According to A. Chaudhry (2013) the "new career" concepts are viewed as "luxury management terms" because they are more akin to the social and economic segments in the Western hemisphere.

The weak relationship between protean career orientation (PCO) and subjective career success (SCS) is also not supporting (Briscoe et al., 2006) who describe protean careerists as proactively managing their careers and making the right career choices that are in congruence with career goals. The findings are contrary to those of other researchers like Abele and Spurk (2009); Fuller Jr and Marler (2009); Seibert et al. (1999) who had found a significant relationship to exist between subjective career success and protean career orientation. Other reasons for the insignificant relationship is that in the competitive environment of Pakistan, academics are more concerned about job security, and climbingup-the-ladder, if they continue to work for the same employer. At the same time, there is a lack of individual and personal development career planning for academics. As all individuals are unique, with different goals which change over time, career planning needs to be conducted in consultation with the employer.

\section{Conclusion}

It is among the pioneer studies on academics working in private universities of Pakistan that establishes relationships based on subjective career success. The study presents a generalized perspective of career satisfaction by taking academics working in the HEC recognized "W" category universities across the country. The present study, meanwhile, has discussed the "new career" concepts of protean career orientation and subjective career success with regards to the private higher education sector of the country. The research thus gives weight to Baruch and Hall (2004) who argued that academic careers are unique and an academic is considered an "autonomous professional" who takes on the responsibility of self-development. The findings, furthermore, can help the HEC in recognizing the importance of the private sector in research and development and will serve as a point of reference for other academics and students.

\section{Theoretical and Practical Implications}

Regarding the relationship between protean career orientation and subjective career success, the concept of PCO has been observed to be not so prevalent among the academics in the present study. Academics are not opening up to career opportunities leading to 
psychological success, i.e. they are not overly-dependent upon externally driven career development opportunities. At the same time, more emphasis has been placed on objective measures of career success such as pay, as it is readily available within the working environment.

The findings are thus in congruence with those of Sullivan and Arthur (2006) who state that PCO is more of a "Western concept" found in industrialized nations, countries where workers are more mobile, and are more focused on material rewards, and promotional gains. Moreover, previous studies as mentioned in the problem statement had discussed location, class size, experience, gender, age, education, pay, promotional prospects, recognition of achievement, administrative support, interpersonal relations, nature of work, autonomy, decision making ability, and fringe benefits as affecting the job success of academics.

Meanwhile, the academics have not yet taken a transition from the "old career" to the "new career". The work processes in "old career" were organized around hierarchical order, centralization, formalities, strict division of labor, fixed blueprints and linear timetables. Moreover, career paths were taken as loyalty-based psychological contracts, and there was a vertical movement seen in terms of income level and status. These objective measures served as means to providing job security to employees in exchange for loyalty.

\section{Limitations}

The first limitation found in the present study is time constraints. Since the study is conducted during the PhD studies, the researcher had to fulfill certain time limits as given in the proposed plan of study. The second limitation is the research on private sector only. Again this point may be related to the previous constraint as the researcher being a student had to be operate under a given time schedule for completion of degree. The third limitation is the use of cross-sectional sampling whereby sampling is done in one-time period rather than having various time periods spread. The fourth limitation is the use of only one dimension of career success. If the researcher has used both the dimensions i.e. subjective and objective a more thorough analysis might be had and, finally, the use of self-reports may inflate the relationships among the proposed hypothesis and chances of common method bias are thus obvious. 


\section{References}

Abele, A. E., \& Spurk, D. (2009). The longitudinal impact of self-efficacy and career goals on objective and subjective career success. Journal of Vocational Behavior, 74(1), 53-62.

Arthur, M. B., Khapova, S. N., \& Wilderom, C. P. (2005). Career success in a boundaryless career world. Journal of Organizational Behavior: The International Journal of Industrial, Occupational and Organizational Psychology and Behavior, 26(2), 177-202.

Baruch, Y., \& Hall, D. T. (2004). The academic career: a model for future careers in other sectors? Journal of Vocational Behavior, 64(2), 241-262.

Bridgstock, R. S. (2007). Success in the protean career: A predictive study of professional artists and tertiary arts graduates (Unpublished doctoral dissertation). Queensland University of Technology.

Briscoe, J. P., \& Finkelstein, L. M. (2009). The "new career" and organizational commitment. Career development international, 14(3), 242-260.

Briscoe, J. P., \& Hall, D. T. (2006). The interplay of boundaryless and protean careers: Combinations and implications. Journal of Vocational Behavior, 69(1), 4-18.

Briscoe, J. P., Hall, D. T., \& DeMuth, R. L. F. (2006). Protean and boundaryless careers: An empirical exploration. Journal of Vocational Behavior, 69(1), 30-47.

Cao, L., Hirschi, A., \& Deller, J. (2013). The positive effects of a protean career attitude for self-initiated expatriates: Cultural adjustment as a mediator. Career Development International, 18(1), 56-77.

Chaudhry, A. (2013). Job satisfaction of university teachers across the demographics (a case of Pakistani universities). Bulletin of Education and Research, 35(1), 1-15.

Chaudhry, S. (2013). Managerial career development in a developing host-country context: A study of American multinationals in Pakistan. The International Journal of Human Resource Management, 24(3), 558-578.

De Vos, A., \& Soens, N. (2008). Protean attitude and career success: The mediating role of self-management. Journal of Vocational Behavior, 73(3), 449-456.

Direnzo, M. S., \& Greenhaus, J. H. (2011). Job search and voluntary turnover in a boundaryless world: A control theory perspective. Academy of Management Review, 36(3), 567-589.

Fuller Jr, B., \& Marler, L. E. (2009). Change driven by nature: A meta-analytic review of the proactive personality literature. Journal of Vocational Behavior, 75(3), 329-345.

Garver, M. S., \& Mentzer, J. T. (1999). Logistics research methods: employing structural equation modeling to test for construct validity. Journal of Business Logistics, 20(1), 33-57.

Greenhaus, J. H., Parasuraman, S., \& Wormley, W. M. (1990). Effects of race on organizational experiences, job performance evaluations, and career outcomes. Academy of Management Journal, 33(1), 64-86.

Grimland, S., Vigoda-Gadot, E., \& Baruch, Y. (2012). Career attitudes and success of managers: The impact of chance event, protean, and traditional careers. The International Journal of Human Resource Management, 23(6), 1074-1094.

Hair, J. F., Black, W. C., Babin, B. J., Anderson, R. E., \& Tatham, R. (2006). Multivariate data analysis . uppersaddle river. NJ: Pearson Prentice Hall. 
Hall, D. T. (2004). The protean career: A quarter-century journey. Journal of Vocational Behavior, 65(1), 1-13.

Hirsch, P. (1988). Pack your own parachute: How to survive mergers, takeovers, and other corporate disasters. Addison-Wesley.

Ng, T. W., Eby, L. T., Sorensen, K. L., \& Feldman, D. C. (2005). Predictors of objective and subjective career success: A meta-analysis. Personnel Osychology, 58(2), 367-408.

Ohbuchi, K.-I., Fukushima, O., \& Tedeschi, J. T. (1999). Cultural values in conflict management: Goal orientation, goal attainment, and tactical decision. Journal of Crosscultural Psychology, 30(1), 51-71.

Seibert, S. E., Crant, J. M., \& Kraimer, M. L. (1999). Proactive personality and career success. Journal of Applied Psychology, 84(3), 416-427.

Sullivan, S. E., \& Arthur, M. B. (2006). The evolution of the boundaryless career concept: Examining physical and psychological mobility. Journal of Vocational Behavior, 69(1), 19-29.

Sullivan, S. E., \& Baruch, Y. (2009). Advances in career theory and research: A critical review and agenda for future exploration. Journal of Management, 35(6), 1542-1571.

Volmer, J., \& Spurk, D. (2011). Protean and boundaryless career attitudes: Relationships with subjective and objective career success. Zeitschrift für ArbeitsmarktForschung, 43(3), 207-218.

Yousaf, A., \& Sanders, K. (2012). The role of job satisfaction and self-efficacy as mediating mechanisms in the employability and affective organizational commitment relationship: A case from a Pakistani university. Thunderbird International Business Review, 54(6), 907-919. 